This item was submitted to Loughborough's Research Repository by the author.

Items in Figshare are protected by copyright, with all rights reserved, unless otherwise indicated.

\title{
Polycentric puzzles - emerging mega-city regions seen through the lens of advanced producer services
}

PLEASE CITE THE PUBLISHED VERSION

http://dx.doi.org/10.1080/00343400802389377

PUBLISHER

Routledge / @ Regional Studies Association

VERSION

AM (Accepted Manuscript)

LICENCE

CC BY-NC-ND 4.0

\section{REPOSITORY RECORD}

Hoyler, Michael, Robert C. Kloosterman, and Martin Sokol. 2019. "Polycentric Puzzles - Emerging Mega-city Regions Seen Through the Lens of Advanced Producer Services”. figshare. https://hdl.handle.net/2134/6182. 
This item was submitted to Loughborough's Institutional Repository (https://dspace.lboro.ac.uk/) by the author and is made available under the following Creative Commons Licence conditions.

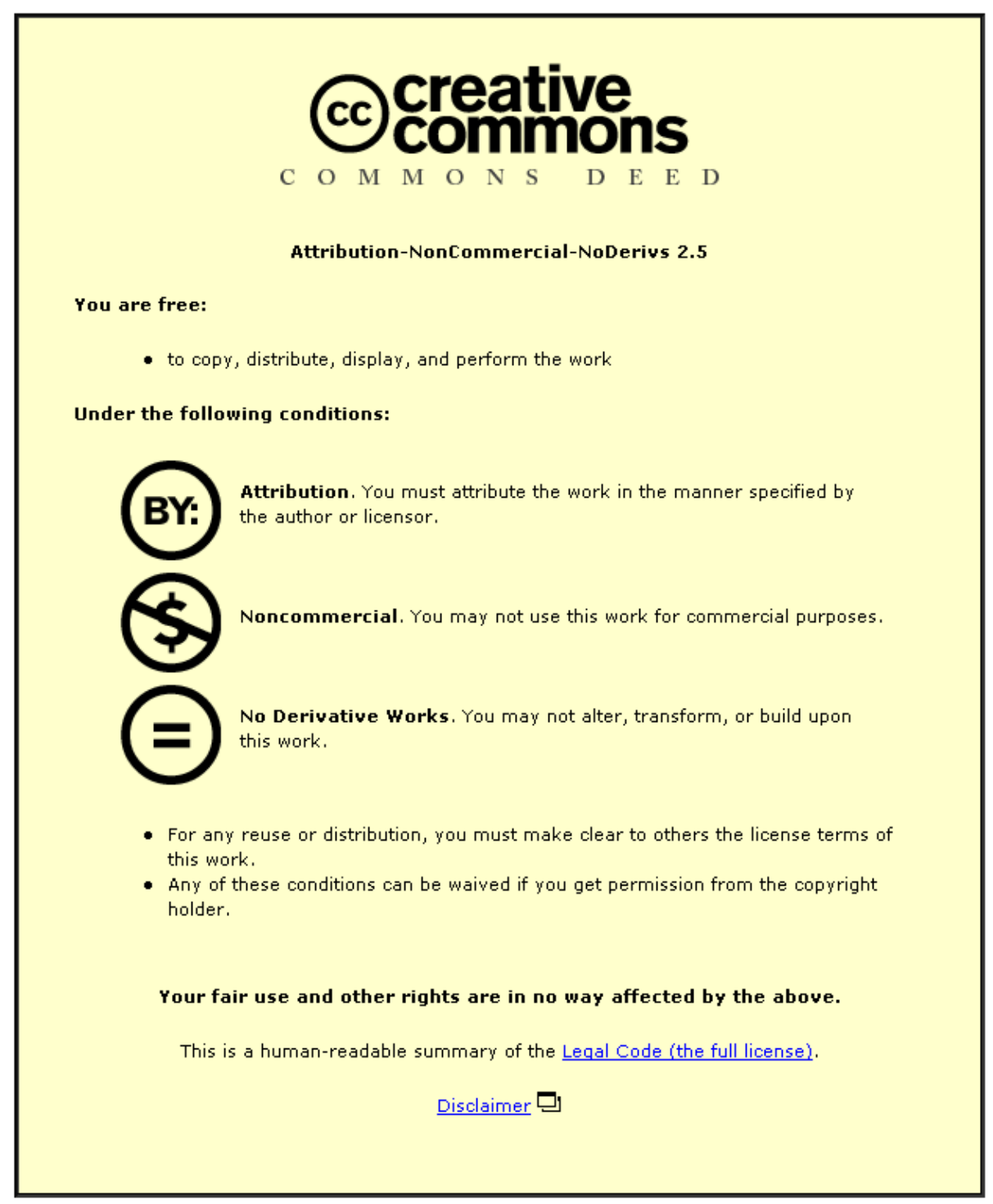

For the full text of this licence, please go to: http://creativecommons.org/licenses/by-nc-nd/2.5/ 


\title{
Polycentric Puzzles - Emerging Mega-City Regions Seen through the Lens of Advanced Producer Services
}

\author{
MICHAEL HOYLER ${ }^{1}$, ROBERT C. KLOOSTERMAN ${ }^{2}$ and MARTIN SOKOL ${ }^{3}$ \\ ${ }^{1}$ Department of Geography, Loughborough University, Loughborough LE11 3TU, \\ UK. Email: M.Hoyler@lboro.ac.uk \\ ${ }^{2}$ AMIDSt, Universiteit van Amsterdam, Nieuwe Prinsengracht 130, NL-1018 VZ \\ Amsterdam, the Netherlands. Email: r.c.kloosterman@uva.nl \\ ${ }^{3}$ Department of Geography, Queen Mary, University of London, Mile End Road, \\ London E1 4NS, UK. Email: m.sokol@qmul.ac.uk
}

\section{INTRODUCTION}

More than half of the world's population lives in cities at the beginning of the twenty-first century (UNFPA, 2007). At the same time, a new type of urban form, first anticipated by GOTTMANN (1961), seems to be emerging across the globe (SIMMONDS and HACK, 2000). This urban form is spread out over a large area, contains a number of cities more or less within commuting distance, and one or more international airports that link the region with other parts of the world. Instead of one dominant central business district, there appear to be multiple centres, many with a strong presence of producer services housed in their telltale concentrations of high-rise buildings. Due to their polycentric structure, these regions tend to display criss-cross commuting patterns, which often result in severe traffic congestion. The emergence of such urban regions in the closing decades of the twentieth century, with an intricate spatial division of labour that clearly comprises more than one central city and its direct hinterland, has, inevitably, caught the 
attention of both academics and policy-makers. Within Europe, the development of large polycentric urban regions has serious implications for the key EU policy issues of competitiveness, social cohesion, and sustainability.

Different attempts have been made to analytically handle these extended urban regions, and a number of labels have been used to denote the identified new metropolitan forms (see also TAYLOR and LANG, 2004); for instance, multi-core metropolis (HALL, 1999), polycentric urban regions (KLOOSTERMAN and MUSTERD, 2001), global city-regions (SCOTT, 2001a), Zwischenstadt (SIEVERTS, 2003), megapolitan areas (LANG and DHAVALE, 2005), megaregions (REGIONAL PLAN ASSOCIATION, 2006), and, as in this issue, mega-city regions (HALL and PAIN, 2006). These different conceptualizations share the above-mentioned core characteristic of polycentricity at the level of an urban region (a term that itself requires further definition), but tend to diverge in their specific meaning and regional scope. We will briefly touch upon some of these approaches in the next section.

In this special issue of Regional Studies, we bring together key results of POLYNET - Sustainable Management of European Polycentric Mega-City Regions, a €2.4 million research project funded by the European Regional Development Fund under the INTERREG IIIB North West Europe programme. ${ }^{1}$ Over a period of three years, this study investigated the anatomy and dynamics of eight North West European 'mega-city regions'2. South East England, the Paris Region, Central Belgium, the Randstad, Rhine- 
Main, RhineRuhr, Northern Switzerland and Greater Dublin. The principal project outcomes, including a full description of research methods and analyses of population, employment and commuting patterns in all study regions, are reported in HALL and PAIN (2006), while the contributions in HALBERT et al. (2006) discuss the policy implications of the research findings in greater depth. ${ }^{3}$ This special issue focuses in detail on the thematic core of the project: the analysis of economic connections and information flows generated by advanced producer services in eight major urban regions in North West Europe. The study started from the premise that business service firms offer a strategic lens to examine inter-city relations within larger urban regions and beyond defined city-regional boundaries, nationally and transnationally, building theoretically on SASSEN's (1991) identification of advanced producer services as crucial actors and outcomes of globalization and localization processes, CASTELLS' (1996) notion of a 'space of flows', and TAYLOR's (2004) concept of a 'world city network'. However, the focus here is on the geographies of concentration and dispersion of advanced producer services beyond the core cities that are at the centre of much of the world and global cities literature.

Specifically, POLYNET aimed to test the hypothesis that 'APS [advanced producer services] knowledge flows extend beyond the global city network to create interlinkages between other cities and towns in North West Europe at a city regional scale, leading to a new phenomenon: the global "mega-city region"' (HALL and PAIN, 2006, p. 14). To study the advanced producer services / inter-city relations nexus, a multi-layered methodology was used. 
This involved a range of quantitative analyses, including the study of intra-firm office networks, to map the geographies of connectivity and flow that bind cities together. These were complemented with qualitative methods; in particular interviews with decision makers in advanced producer service firms, who through their locational strategies exert considerable influence on the spatial structure of urban regions and their integration into wider economic networks. As a study into the relational and scalar geographies of polycentric city-regions, the POLYNET project was a first attempt to make the often invisible contours of mega-city regions in North West Europe visible (see also THIERSTEIN and FÖRSTER, 2008). The research reported here therefore aims to contribute to what SCOTT (2001a, p. xiv) called 'a deeply contentious and urgent debate' about emerging 'global city-regions' (see also SCOTT, 2001b) and the challenges they pose for policy-makers around the world, a debate that is now in full swing (e.g. OECD, 2006; SEGBERS, 2007; DEWAR and EPSTEIN, 2007; GOLDFELD, 2007; MEIJERS, 2007; LANG and KNOX, 2008).

In this introduction, we first briefly discuss key elements of the debates that informed the research project and point out some unresolved gaps in our understanding of polycentric city-regions. We then summarize the main findings of the contributions of this issue and conclude by presenting a possible agenda for future research on emerging mega-city regions. 


\section{GLOBALIZATION, CITY-REGIONS AND POLYCENTRICITY}

In recent years, major developments have taken place in both theory and policy debates on globalization, city-regions and polycentricity. Above all, there has been a spectacular surge of interest in cities and regions and their role in the global knowledge economy. This has been accompanied by suggestions that the simultaneous processes of globalization and knowledgeintensification of economies have produced a 'new spatial logic' (CASTELLS, 1989). However, key theorists have argued that within this 'new spatial logic' the significance of agglomeration has not melted away. Quite the opposite cities and city-regions have gained new prominence.

Thus, for CASTELLS (1989) the 'informational city' represents the emerging 'new spatial logic' born out of a tension between the 'space of flows' and the 'space of places' in the 'informational economy' or 'network society' (CASTELLS, 1996). SASSEN (1991, p. 4) argues that 'a new type of city has appeared' in the form of the 'global city'. Amid complex changes of the global economy, major cities have acquired, in her view, a 'new strategic role' in particular with regard to knowledge-intensive, advanced business services. In turn, TAYLOR (2004) proposes that the interconnectedness of these advanced producer services has created a 'world city network' in which cities operate as global service centres. Both SASSEN (1991) and TAYLOR (2004) initially focused their attention on the functional centrality of cities rather than their wider city-regional context. 
Elsewhere, however, the broader context of the region was taken into account. CASTELLS (1989, p. 167), for instance, argues that the new spatial logic is marked by the creation of 'multifunctional, multinuclear spatial structures'. SCOTT (2001a, p. 1) develops a broader regional view and sees 'global city-regions' as new 'regional social formations'. These city-regions are undergoing a major transformation due to the impact of globalization; they perform a 'deepening role as points at which globalization processes crystallize out on the geographical landscape' (SCOTT, 2001a, p. 7). Furthermore, city-regions are 'active agents in shaping globalization itself' (SCOTT, 2001a, p. 7) and can be labelled as 'basic motors' (SCOTT, 2001a, p. 4) or 'essential spatial nodes of the global economy' (SCOTT et al., 2001, p. 11). Scott and his colleagues state that:

'most metropolitan regions in the past were focused mainly on one or perhaps two clearly defined central cities, the city-regions of today are becoming increasingly polycentric or multiclustered agglomerations' (SCOTT et al., 2001, p. 18; emphasis added).

In a similar vein, Peter Hall points to the emergence of a 'multi-core metropolis' (HALL, 1999, p. 19). Elsewhere, he argues that contemporary global city-regions are characterized by an extremely complex and sophisticated internal geography that is 'quintessentially polycentric' (HALL, 2001, p. 73). 
SASSEN (2001, p. 85) contends that city centres can extend into a metropolitan area in the form of a 'grid of nodes' of intense business activity. For her, the regional grid of nodes represents a 'reconstitution of the concept of region' amid emerging 'new geographies of centrality (and marginality)', although this 'grid of nodes' is clearly smaller than the wider mega-city region (DERUDDER, 2006). More recently, SASSEN (2007, p. 60) has argued that 'the specific advantages of the megaregional scale consist of and arise from the coexistence within one regional space of multiple types of agglomeration economies'. According to this argument, the underlying spatial logic is not just based on urbanization economies (advantages of scale and spatial concentration) but also on localization economies.

These mega-city regions then encompass two different logics of economic organization and of global linkages (KLOOSTERMAN and LAMBREGTS, 2007). One the one hand, we find the globally linked advanced producer services highly concentrated in one city, as analysed by SASSEN and TAYLOR. The specific requirements for these 'commanding heights of capitalism' generate strong urbanization economies (JACOBS, 1969) and benefit, in particular, large cities. These cities constitute the higher echelons of a global network of cities, based on headquarters and other offices of transnational firms and producer services, on (international) accessibility (both physical and virtual), and on perceived quality of life. On the other hand, we find a different type of economic organization that is also very much part of the global economy. Many highly specialized, high-skilled economic activities are spatially clustered, too, but not necessarily in the primate city that houses 
the advanced producer services. These clusters are first and foremost dependent on more specific or localization economies and can, in principle, be located anywhere within a mega-city region. We find, for instance, highquality knitwear in the Italian province of Modena, advanced automotive engineering (Porsche and Mercedes-Benz) in the German city-region of Stuttgart (COOKE and MORGAN, 1998), or world-class architectural design in Rotterdam (KLOOSTERMAN, 2008). The firms in these clusters thrive on the combination of local embeddedness (STORPER, 1997) and global pipelines (BATHELT et al., 2004; CUMBERS and MACKINNON, 2004). As these clusters are to some extent dependent on the same infrastructure as advanced producer services (e.g. proximity to an international airport, ICT infrastructure) and the presence of a highly skilled labour force, and as they are, moreover, directly dependent on advanced producer services to link up with the global economy, these clusters are more likely to be found within mega-city regions than outside. They may thus contribute to a specific polycentric pattern, whereby different highly specialized clusters are scattered within one mega-city region, with one primate city specializing in advanced producer services and serving as a global gateway and node. The POLYNET project, however, did not investigate these different sets of agglomeration forces, nor did it focus on potential synergies in polycentric urban regions (MEIJERS, 2007). We will come back to these issues below when we propose a renewed research agenda.

The view that mega-city regions are taking on a specific spatial form is gaining ground. Many urbanists now seem to agree that these regions are becoming 
increasingly multinuclear or polycentric. However, the key question is what implications this may have for competitiveness and balanced spatial development. Two contrasting positions can be identified. On the one hand, it is hypothesized that polycentric urban regions have potential competitive advantages over monocentric regions and that they derive considerable economic strength from their polycentric structure (HALL, 1997; LAMBOOY, 1998; BAILEY and TUROK, 2001). On the other hand, it has been argued that the 'culturally heterogeneous, polycentric, socially and spatially segmented global city-region is ... a highly fragmented chess-board of uneven development sprawling ever outward' (SCOTT et al., 2001, p. 20), thus representing a major challenge in terms of social and spatial cohesion and, increasingly, also in terms of sustainability (WHEELER, 2008).

These are precisely the issues that policy-makers are facing around the world. Indeed, rising competitive pressures, said to emanate from combined processes of globalization and increasing knowledge-intensity of economic activities, accompanied by growing social and spatial inequalities, create new policy imperatives. Policy-makers at all spatial levels are preoccupied with the question of how to guarantee competitiveness and, at the same time, to safeguard cohesion. This policy dilemma is perhaps most apparent in Europe, striving to be the most competitive and socially inclusive knowledge economy in the world (EUROPEAN UNION, 2000). However, amid difficulties of achieving the above self-imposed target there is a growing realization that city-regions may be central arenas with regard to both objectives. The European Spatial Development Perspective (ESDP) is perhaps the best 
example of this. The document has introduced the concept of 'balanced competitiveness' and argued that polycentricity is the best tool for achieving it at both European and city-regional levels (EUROPEAN COMMISSION, 1999). In an interesting circle then, policy agendas and theory developments seem to come happily together: the tendencies identified by academics are at the same time promoted by policy-makers. However, there are several key problematic issues with regard to 'polycentric city-regions' to which we now turn.

While the above theory and policy developments constitute a major shift in our approach to spatial urban forms at the beginning of the twenty-first century, many questions remain unanswered. Crucially, despite the proclaimed importance of polycentric global city-regions, there are serious gaps in our understanding of this phenomenon. Indeed, several interrelated challenges need to be addressed.

Lack of conceptual clarity

Some basic conceptual building blocks still await a thorough definition, including the key terms of 'city-region' and 'polycentricity'. These are currently used very loosely, indeed can be characterized as 'fuzzy concepts' (MARKUSEN, 1999) that render the conceptualization of a polycentric 'global city-region' rather problematic. Current definitions of polycentricity usually combine morphological characteristics and functional relations, and this 
contributes to a conflation of two analytically distinct dimensions of polycentricity. The various approaches, in addition, cover a whole array of causes and drivers. They can be economic (e.g. disintegration of value chains in combination with spatial concentration of co-ordination tasks; globalization versus localization); technological (e.g. ICT developments); infrastructural (e.g. mass-commuting by car or public transport in combination with centralized international airport or high speed train hubs); or simply demographic (population growth and urban sprawl). In addition, analytical and prescriptive or normative approaches co-exist, sometimes without a clear demarcation line. There is no doubt that further conceptual work is needed to clarify the meaning of 'polycentricity' in specific urban and regional contexts (e.g. KLOOSTERMAN and LAMBREGTS, 2001; DAVOUDI, 2003; CATTAN, 2005; PARR, 2004, 2005; TUROK and BAILEY, 2004; LAMBREGTS, 2006; MEIJERS, 2007).

Lack of detailed empirical evidence

The absence of a clear conceptualization makes the empirical investigation into polycentric city-regions a challenging task. As the different approaches focus on a variety of aspects of polycentricity and their underlying causes, the existing empirical evidence is at best fragmented and disjointed, as can be gleaned from previous special issues of Urban Studies $(38.4,2001)$ and European Planning Studies $(6.4,1998,12.3,2004)$. We can also observe an array of methods and indicators to capture the polycentric character of 
specific city-regions (e.g. city size rankings; commuter data; firm dynamics; changes in economic profiles; telecommunication flows). There is therefore a lack of systematic evidence on the changing internal geographies of megacity regions and the potentially synergetic effects of polycentricity (PARR, 2004; CHESHIRE, 2006). Equally, there is a need for a more detailed understanding of functional integration of various economic activities within city-regions and their interconnectedness with the global economy.

Problematic policy agenda

The lack of a sound conceptual framework and the weak empirical evidence make policies that promote 'polycentricity' rather problematic (KRÄTKE, 2001; DAVOUDI, 2003). In particular, the implications for competitiveness and cohesion remain uncertain. An example of this is a situation where the promotion of polycentricity at one scale (e.g. Europe-wide) may lead to increased monocentricity at another scale (e.g. nationally). Furthermore, centrifugal forces that lie behind increasing polycentricity do not necessarily support the kind of balanced and sustainable development that policy-makers would like to see. Instead, spatially fragmented and unevenly developed agglomerations may emerge (SCOTT et al., 2001). Such city-regions present major socio-economic, transport-related and environmental challenges. Addressing these successfully may additionally be hampered by politicoadministrative fragmentation and a concomitant lack of strategic planning capacities (HERRSCHEL and NEWMAN, 2002; HOYLER et al., 2006). 


\section{ADVANCED PRODUCER SERVICES IN NORTH WEST EUROPEAN MEGA-CITY REGIONS}

This special issue aims to move forward the theoretical debate on large polycentric urban regions on the basis of new empirical evidence from North West Europe. The first two contributions provide a conceptual introduction to the POLYNET study and an initial comparative quantitative analysis of advanced producer service linkages that integrate the eight mega-city regions into wider economic networks. This is followed by seven regional case studies that explore the 'mega-city region' hypothesis based on evidence gathered during POLYNET and through other complementary work. Each regional case study follows its own thematic and methodological perspective to develop a context-specific argument for its city-region. The final paper takes a European view and critically addresses the promotion of polycentricity in European spatial planning.

In the first contribution, Kathy Pain and Peter Hall outline the theoretical framework of the POLYNET project. They introduce four central concepts the mega-city region, polycentricity, advanced producer services, and information flows - and critically discuss the varied methodological approaches undertaken to study mega-city regional processes in North West Europe. Pain and Hall conclude with a brief overview of key conclusions of POLYNET that set the scene for the following papers. 
Peter Taylor, David Evans and Kathy Pain provide a comparative analysis of functional polycentricity for the eight mega-city regions studied in POLYNET. Taking their lead from the world city literature, the authors adapt TAYLOR's (2001) interlocking network model, originally devised to study inter-city relations at the global scale, to measure polycentricity within and beyond cityregions. A key result of their study is the scale-dependency of functional polycentricity. The authors identify a general decline in polycentricity with increasing scale (with considerable variation between the eight mega-city regions) and convincingly argue that polycentricity should not be viewed as a simple singular property of a city-region.

In the first regional case study, Michael Hoyler, Tim Freytag and Christoph Mager further explore the multi-scalar polycentricities produced by business services. They address the question how intra-firm linkages of advanced producer service firms in Rhine-Main connect the region internally and externally across multiple scales. Frankfurt's dominant position as 'first city' in Rhine-Main is confirmed at all scales but is particularly pronounced at national, European and global scales, where functional polycentricity is weak. Despite Frankfurt's primacy at larger scales and its significant gateway role, the paper identifies sector-specific complementary network patterns of advanced producer services that connect the other cities of Rhine-Main to the wider German economy.

Alain Thierstein, Stefan Lüthi, Christian Kruse, Simone Gabi and Lars Glanzmann use evidence from both intra-firm and inter-firm networks of 
advanced producer services to identify an emerging mega-city region in Northern Switzerland, focused on the two main centres Zurich and Basel. In their analysis of changing value chains in the Swiss knowledge economy, the authors note an increasing concentration of highly advanced functions in a few centres and a dispersion of associated functions into the wider mega-city region. The authors conclude that the identified functional spaces of economic interrelation that constitute the mega-city region Northern Switzerland have yet to be taken seriously by policy-makers whose attention remains primarily directed to the local scale.

In contrast to the Swiss case, Martin Sokol, Chris van Egeraat and Brendan Williams find little evidence for an emerging polycentric city-region Greater Dublin. Knowledge-intensive business services in Dublin remain concentrated in the metropolitan area and show no significant signs of outward diffusion into the wider city-region apart from some subordinate support functions. The authors analyse corporate strategies, labour market conditions, and the role of the state to account for the observed lack of functional polycentricity in Greater Dublin that sits uneasily with CASTELLS' (1989) concept of the 'informational city', and thus problematize the claim that a dramatically 'new spatial logic' is emerging.

Ludovic Halbert is similarly sceptical in his examination of the mega-city region hypothesis for the Paris city-region. Based on the analysis of population and employment figures and information flows measured by telephone calls between firms, he too finds little evidence for the dispersion of 
advanced producer services from the lle-de-France to the wider region of the Bassin parisien. While a functional division of labour exists between Paris and the Paris city-region, the French global 'space of centrality' remains firmly located in the central metropolitan triangle marked by the western districts of Paris, La Défense, and Boulogne-Billancourt/lssy-les-Moulineaux. Halbert explains the limited regional polycentricity with reference to the strategies of real estate developers, advanced producer service firms, and the history of spatial planning policies for Paris and its wider region.

Examining Europe's dominant global city, London, and the South East England region, Kathy Pain on the other hand uncovers a dense web of interurban linkages that connect the 'first city' London with its extended hinterland. Her analysis of interviews with senior managers in advanced producer services in London and eight other urban centres in South East England reveal 'intense virtual and physical flows', fuelled by London's role as global hub for the creation of high value business knowledge. In contrast to other regions studied in POLYNET, such as the Randstad, RheinRuhr or RhineMain, Pain finds little evidence for sectoral specialization in the regional centres outside London. The growth of advanced producer services in the wider South East England region is seen as additional to growth in central London rather than a result of net decentralization.

Bart Lambregts also uses evidence from corporate interviews, in the Dutch Randstad, to explore in more detail the geographies of knowledge formation in advanced producer services. He argues that the global players among the 
region's business services are strongly constitutive of external knowledge relations, which he sees as key to enhance regional competitiveness. Lambregts explores which types of knowledge are typically acquired by advanced producer service firms within the mega-city region and which types may travel - notably through the firms' office networks - between city-regions with relative ease. He finds that the need for operational market-related knowledge ties such firms to a specific location and that some types of product-related knowledge may be acquired over larger distances. The polycentric layout of the Randstad and the consequent spatially dispersed availability of sources from which to derive market-related information, may explain why many firms service the region through several offices rather than through one.

Wolfgang Knapp and Peter Schmitt examine the notion of a mega-city region RhineRuhr within the new metropolitan policy discourse in Germany. They observe a process of re-scaling that promotes a number of 'European Metropolitan Regions' as engines of economic growth in Germany's polycentric urban system. The cities in RhineRuhr, the POLYNET region with the highest degree of functional polycentricity at all scales, are characterized by a high degree of sectoral division of labour and functional specialization. However, political cooperation in the region is hindered by a lack of a shared regional vision and continued competitive localism.

Christian Vandermotten, Ludovic Halbert, Marcel Roelandts and Pierre Cornut conclude this special issue with a critical engagement with polycentrism, the 
normative promotion of greater polycentricity in the European urban system that aims to achieve both competitive growth and sustainable balanced spatial development. The authors provide a theoretical and methodological critique of the ESPON 1.1.1 study on polycentric development in Europe (ESPON, 2005) and question the assumptions that underlie many EU policy documents that explicitly advocate polycentricity (e.g. the ESDP).

The various contributions to this issue show that the mega-city region is not merely a theoretical construct but, in some cases, can indeed be identified in social reality. There is, however, considerable variation between the different regions, which defies easy generalization by researchers and policy-makers. These differences can be attributed to several factors:

First, there is the effect of the morphology of a specific urban system or, in other words, the sunk-costs of the built environment and its associated social structures, which mould and shape the impact of globalization/localization and concentration/deconcentration. The urban systems in, for instance, the Dutch Randstad and German RhineRuhr, have a very different morphological makeup compared to the ones of Paris and London. The historical legacy of concentration and accumulation in national urban systems with its associated particular population distribution, infrastructural networks, governance structures and national planning arrangements impinge on the locational decisions of advanced producers services and, hence, on the functional relations within the mega-city region (KLOOSTERMAN and LAMBREGTS, 2007). 
Second, the nature and extent of functional relationships within and between mega-city regions is to some degree dependent on the characteristics of advanced producer services in a particular region. The leverage of business service firms is related to the size of their home market and, increasingly, to their role in global markets. The leading position of London in global finance, for example, is mirrored in the size and importance, in absolute and relative terms, of its advanced producer service sector (BEAVERSTOCK et al., 2001; TAYLOR et al., 2003). Further to this, it is important to note that, despite some commonalities, the functional and spatial organization of advanced producer service firms does not follow some kind of universal logic. Indeed, significant differences can be found between and within individual advanced producer service sectors. The financial services sector, for instance, operates through a diversity of geographies (Sokol, 2007) with important bearings on the pattern of internal and external relations of a given mega-city region.

Third, location decisions of advanced producer services are not taken in a vacuum, but instead in a complex arena of context-specific rules and regulations where public (e.g. urban planners) and private actors (e.g. real estate developers) meet.

Another finding is that processes of concentration and deconcentration occur simultaneously in mega-city regions. It seems that high-end advanced producer services continue to concentrate within the leading city/cities, whereas activities with lower value-added are moving out of the centres, 
either to suburban locations or into the wider urban region. In other words: advanced global functions tend to concentrate strongly in just one 'first city' as this is where they can find a suitable environment with other globally organized firms and related supporting producer services, prime office space, and a cosmopolitan climate and associated amenities. This finding suggests a process of nested globalization whereby the crucial global linkages within the mega-city region appear to run through the first city (and within that city through a special part of the city) and from there to the rest of the region and beyond (see also SASSEN, 2001, 2007). This is in line with the observation that the mega-city region is still very much a differentiated space in terms of density, infrastructural endowments, economic activities, mix of functions, and social, cultural and ethnic composition of the population.

\section{AN UPDATE OF THE RESEARCH AGENDA}

The mega-city region, in its various guises, is becoming a more general phenomenon in advanced and, arguably, in emerging economies. Research on urban issues should, at least partly, be refocused to take into account the complex and dynamic picture of different sets of cities connected through first city hubs that provide the environment for high end 'connecters' such as advanced producer services. Some extensions of the POLYNET project are already underway, both in terms of expanding the scale of analysis from regional to national (TAYLOR et al., 2007), and in terms of adding other knowledge-intensive sectors to the analysis, such as high-tech firms (LÜTHI 
et al., 2008). Below we will suggest a research agenda beyond the immediate parameters of POLYNET, following the triad of competitiveness, social cohesion and sustainability that underpins viable cities and city-regions.

\section{Competitiveness}

Advanced producer service firms are important in helping to boost and, arguably, even create competitiveness (KAY, 2004). The POLYNET project used these services as a lens to observe inter-city relations. We now seem to be witnessing a redistribution of advanced producer services with a deconcentration of lower-value added activities and a concentration of highvalue-added activities in the first city. As these latter activities function as an interface - perhaps even gatekeeper - between firms elsewhere in the region and the global markets, it is imperative to go beyond the POLYNET lens and look at the relations of firms that actually (intend to) export to global markets. How do they find suppliers/clients globally and where, if at all, do advanced producer services come into play? Are there, in other words, also significant lateral network-type relations that bypass the advanced producer services in the first city? Is the global economy, thus, less hierarchical than it seems to manifest itself in this project? What complementarities between the different forms of spatial logic do arise within the mega-city regions?

A second issue considers not so much the relationship between the first city and the rest, but the dynamics within these first cities themselves. The 
combined process of concentration of high-end and deconcentration of lowend services may accelerate further. This process of increasing returns in combination with expanding financialization might crowd-out other economic activities and erode the diversity of the economic base of the first cities. Processes of innovation are dependent upon sheltered spaces where new, unorthodox insights and knowledge can be generated. To rephrase this in the form of a question: is the economic (and social) diversity within the central city under threat due to the increasing role of high-end producer services and, if so, does the mega-city region as a whole offer a palette of sufficiently different milieus that include, for example, also incubator spaces for cultural industries?

Social cohesion

So far, little research has been directed towards the issue of social cohesion at the scale of polycentric regions, and the contributions in this special issue are no exception. Inequality and social cohesion within the context of these evolving mega-city regions, however, without any doubt appear on the agenda of policy-makers, and both drivers and consequences should be addressed in future research. According to SASSEN (2001) the first or global cities within global city-regions are both richer and poorer than the other cities. What are the implications of this for the social cohesion within these cities and, on a higher level of scale, on that of the mega-city region itself? Are these city-regions becoming more polarized? To what extent can polarization be attributed to the first city functioning as a social escalator, whereby (young) 
people from elsewhere move to the first city to climb the steps of the social ladder and then move out again? More generally, how are spatial aspects of the life cycle of different groups related to the emergence of mega-city regions? Which groups are stuck in the basement (sometimes even literally) of the first cities?

\section{Sustainability}

It seems highly likely that costs of spatial mobility will rise further in the near future, as energy prices will increase even more and (national and local) governments will impose (higher) taxes and other measures to curb the emission of greenhouse gases. How will this affect the internal relations, partly based on mass-commuting, within mega-city regions? Will we see a rise of multiple location households (second homes) to straddle the demands of being present in high-density, frequent contact 'first cities', and the desire for space (and what does this mean for mobility not just on a daily, but also on a weekly and even monthly basis)? Other sustainability issues that pose particular challenges at the megaregional scale include the management of resources such as water and agricultural land, increasing intra and interregional disparities and resulting equity issues, as well as questions of community-building and identity formation in mega-city regions (WHEELER, 2008). 
The above-mentioned issues are just some of the more pressing research lines that could be pursued building on the findings of the work reported here and other projects in the field. This new research agenda, however, may also require new methodological approaches. As documented in this special issue, the POLYNET study explored a range of methods that go well beyond a simple measurement of commuter flows in polycentric urban regions. In particular, the combination of quantitative and qualitative research has been fruitful. But more can be done. For instance, new possibilities are now opening up as combinations of qualitative research and GIS techniques enable researchers to map the movements in the ostensibly panta rhei of mega-city regions in a way that was hitherto impossible (KWAN and KNIGGE, 2006). Importantly, polycentricity appears to be a multi-layered phenomenon with each layer displaying a distinctive spatial pattern. Investigating the underlying processes thus requires a variety of methods, from those measuring commuting to those capturing knowledge spillovers among advanced producer services. Future research should aim to combine different aspects of polycentricity in a systematic way, for example by creatively engaging GIS techniques that may allow a more comprehensive analysis of how these are interrelated.

Finally, it remains to be seen in what way the insights gained from studying eight North West European mega-city regions compare with evidence from emerging megaregional urban forms and experiences outside of Europe. 
Such a truly global perspective would also help to further elucidate the extent to which the formation of mega-city regions represents a gradual reworking of inherited urban structures or a genuinely new and qualitatively different spatial logic.

\section{Acknowledgements}

POLYNET was funded by the European Union under the INTERREG IIIB North West Europe programme and received additional support from a range of institutions in each participating country, all of whom are thanked for making the project possible. Thanks also to all the contributors to this special issue; to the manuscript reviewers; and to the large number of interviewees who participated in the study. Bart Lambregts provided helpful comments on an earlier version of this introductory paper. The authors also thank the

Regional Studies editorial team, especially Andy Gillespie as overseeing Editor for this special issue, and Gail Welsh for her invaluable assistance throughout the review process.

\section{REFERENCES}

AUJEAN L., CASTIAU E., ROELANDTS M. and VANDERMOTTEN C. (2007) Le positionnement des villes belges dans le réseau global des services avancés, Belgeo 2007/1, 15-30. 
BAILEY N. and TUROK I. (2001) Central Scotland as a polycentric urban region: useful planning concept or chimera? Urban Studies 38, 697-715.

BATHELT H., MALMBERG A. and MASKELL P. (2004) Clusters and knowledge: local buzz, global pipelines and the process of knowledge creation, Progress in Human Geography 28, 31-56.

BEAVERSTOCK J.V., HOYLER M., PAIN K. and TAYLOR P.J. (2001) Comparing London and Frankfurt as World Cities: A Relational Study of Contemporary Urban Change. Anglo-German Foundation for the Study of Industrial Society, London.

CASTELLS M. (1989) The Informational City: Information Technology, Economic Restructuring and the Urban-Regional Process. Blackwell, Oxford.

CASTELLS M. (1996) The Rise of the Network Society. Blackwell, Oxford.

CATTAN N. (Coordination) (2005) Critical Dictionary of Polycentrism. Annex Report A, ESPON 1.1.1: Potentials for Polycentric Development in Europe. (available at: http://www.espon.eu) (accessed on 19 May 2008).

CHESHIRE P.C. (2006) Resurgent cities, urban myths and policy hubris: what we need to know, Urban Studies 43, 1231-1246. 
COOKE P. and MORGAN K. (1998) The Associational Economy: Firms, Regions, and Innovation. Oxford University Press, Oxford.

CUMBERS A. and MACKINNON D (2004) Introduction: clusters in urban and regional development, Urban Studies 41, 959-969.

DAVOUDI S. (2003) Polycentricity in European spatial planning: From an analytical tool to a normative agenda, European Planning Studies 11, 979999.

DERUDDER B. (2006) On conceptual confusion in empirical analyses of a transnational urban network, Urban Studies 43, 2027-2046.

DEWAR M. and EPSTEIN D. (2007) Planning for "megaregions" in the United States, Journal of Planning Literature 22, 108-124.

ESPON (EUROPEAN SPATIAL PLANNING OBSERVATION NETWORK) (2005) ESPON 1.1.1: Potentials for Polycentric Development in Europe. Project Report. (available at: http://www.espon.eu) (accessed on 19 May 2008).

EUROPEAN COMMISSION (1999) ESDP European Spatial Development Perspective: Towards Balanced and Sustainable Development of the Territory of the European Union. Office for Official Publications of the European Communities, Luxembourg. 
EUROPEAN UNION (2000) Lisbon Extraordinary European Council, 23-24 March 2000: Presidency Conclusions. European Council / European Union, Brussels.

GOLDFELD K.S. (Ed) (2007) The Economic Geography of Megaregions. The Policy Research Institute for the Region, Princeton, NJ.

GOTTMANN J. (1961) Megalopolis: The Urbanized Northeastern Seaboard of the United States. The Twentieth Century Fund, New York.

GREEN N. (2007) Functional polycentricity: A formal definition in terms of social network analysis, Urban Studies 44, 2077-2103.

HALBERT L., CONVERY F. and THIERSTEIN A. (Eds) (2006) Reflections on the Polycentric Metropolis. Built Environment 32(2).

HALL P. (1997) The future of the metropolis and its form, Regional Studies 31, 211-220.

HALL P. (1999) Planning for the mega-city: A new Eastern Asian urban form? in BROTCHIE J., NEWTON P., HALL P. and DICKEY J. (Eds) East West Perspectives on 21st Century Urban Development: Sustainable Eastern and Western Cities in the New Millennium, pp. 3-36. Ashgate, Aldershot. 
HALL P. (2001) Global city-regions in the twenty-first century, in SCOTT A.J.

(Ed) Global City-Regions: Trends, Theory, Policy, pp. 59-77. Oxford University Press, Oxford.

HALL P. and PAIN K. (Eds) (2006) The Polycentric Metropolis: Learning From Mega-City Regions in Europe. Earthscan, London.

HERRSCHEL T. and NEWMAN P. (2002) Governance of Europe's City Regions: Planning, Policy and Politics. Routledge, London.

HOYLER M., FREYTAG T. and MAGER C. (2006) Advantageous fragmentation? Reimagining metropolitan governance and spatial planning in Rhine-Main, Built Environment 32, 124-136.

JACOBS J. (1969) The Economy of Cities. Random House, New York.

KAY J. (2004) The Truth About Markets: Why Some Nations Are Rich But Most Remain Poor. Penguin, London.

KLOOSTERMAN R.C. (2008) Walls and bridges: knowledge spillover between 'superdutch' architectural firms, Journal of Economic Geography 8, 545-563. 
KLOOSTERMAN R.C. and LAMBREGTS B. (2001) Clustering of economic activities in polycentric urban regions: the case of the Randstad, Urban Studies 38, 717-732.

KLOOSTERMAN R.C. and LAMBREGTS B. (2007) Between accumulation and concentration of capital: Comparing the long-term trajectories of the Dutch Randstad and London urban systems, Urban Geography 28, 54-73.

KLOOSTERMAN R.C. and MUSTERD S. (2001) The polycentric urban region: towards a research agenda, Urban Studies 38, 623-633.

KRÄTKE S. (2001) Strengthening the polycentric urban system in Europe: conclusions from the ESDP, European Planning Studies 9, 105-116.

KWAN M.P. and KNIGGE L. (2006) Doing qualitative research using GIS: an oxymoronic endeavor? Environment and Planning A 38, 1999-2002.

LAMBOOY J.G. (1998) Polynucleation and economic development: The Randstad, European Planning Studies 6, 457-466.

LAMBREGTS B. (2006) Polycentrism: boon or barrier to metropolitan competitiveness? The case of the Randstad Holland, Built Environment 32 , 114-123.

LANG R. and DHAVALE D. (2005) America's megapolitan areas, Land Lines 
17 (available at: http://www.lincolninst.edu/pubs/PubDetail.aspx?pubid=1039) (accessed on 19 May 2008).

LANG R. and KNOX P.L. (2008) The new metropolis: rethinking megalopolis, Regional Studies, doi:10.1080/00343400701654251.

LÜTHI S., THIERSTEIN A. and GOEBEL V. (2008) Intra-firm and extra-firm linkages of the knowledge economy - the case of the mega-city region of Munich, GaWC Research Bulletin 269 (available at: http://www.lboro.ac.uk/gawc/rb/rb269.html) (accessed on 19 May 2008).

MARKUSEN A. (1999) Fuzzy concepts, scanty evidence, policy distance: the case for rigour and policy relevance in critical regional studies, Regional Studies 33, 869-884.

MEIJERS E. (2007) Synergy in Polycentric Urban Regions: Complementarity, Organising Capacity and Critical Mass. Delft University Press, Delft.

OECD (2006) Competitive Cities in the Global Economy (OECD Territorial Reviews). Organisation for Economic Co-operation and Development, Paris.

PARR J.B. (2004) The polycentric urban region: a closer inspection, Regional Studies 38, 231-240. 
PARR J.B. (2005) Perspectives on the city-region, Regional Studies 39, 555566.

REGIONAL PLAN ASSOCIATION (2006) America 2050: A Prospectus. Regional Plan Association, New York.

SASSEN S. (1991) The Global City: New York, London, Tokyo. Princeton University Press, Princeton, NJ.

SASSEN S. (2001) Global cities and global city-regions: a comparison, in SCOTT A.J. (Ed) Global City-Regions: Trends, Theory, Policy, pp. 78-95. Oxford University Press, Oxford.

SASSEN S. (2007) Megaregions: benefits beyond sharing trains and parking lots? in GOLDFELD K.S. (Ed) The Economic Geography of Megaregions, pp. 59-83. The Policy Research Institute for the Region, Princeton, NJ.

SCHMITT P. and KNAPP W. (2006) RheinRuhr als polyzentrischer „Raum der Orte“ im „Raum der Ströme“, Zeitschrift für Wirtschaftsgeographie 50, 217231.

SCOTT A.J. (Ed) (2001a) Global City-Regions: Trends, Theory, Policy. Oxford University Press, Oxford.

SCOTT A.J. (2001b) Globalization and the rise of city-regions, European 
Planning Studies 9, 813-826.

SCOTT A.J., AGNEW J., SOJA E. and STORPER M. (2001) Global cityregions, in: SCOTT A.J. (Ed), Global City-Regions; Trends, Theory, Policy, pp. 11-30. Oxford University Press, Oxford.

SEGBERS K. (Ed) (2007) The Making of Global City Regions: Johannesburg, Mumbai/Bombay, São Paulo, and Shanghai. Johns Hopkins University Press, Baltimore, MD.

SIEVERTS T. (2003) Cities Without Cities: An Interpretation of the Zwischenstadt. Spon Press, London.

SIMMONDS R. and HACK G. (Eds) (2000) Global City Regions: Their Emerging Forms. Spon, London.

SOKOL M. (2007) Space of flows, uneven regional development, and the geography of financial services in Ireland, Growth and Change 38, 224-259.

STORPER M. (1997) The Regional World: Territorial Development in a Global Economy. Guilford Press, New York.

TAYLOR P.J. (1999) Worlds of large cities: pondering Castells' space of flows, Third World Planning Review 21, iii-x. 
TAYLOR P.J. (2001) Specification of the world city network, Geographical Analysis 33, 181-194.

TAYLOR P.J. (2004) World City Network: A Global Urban Analysis. Routledge, London.

TAYLOR P.J. and LANG R.E. (2004) The shock of the new: 100 concepts describing recent urban change, Environment and Planning A 36, 951-958.

TAYLOR P.J., BEAVERSTOCK J.V., COOK G., PANDIT N., PAIN K. and GREENWOOD H. (2003) Financial Services Clustering and its Significance for London. Corporation of London, London.

TAYLOR P.J., EVANS D.M., HOYLER M., DERUDDER B. and PAIN K. (2007) The UK space economy as practised by advanced producer service firms: identifying two distinctive polycentric city-regional processes in contemporary Britain, GaWC Research Bulletin 227 (available at: http://www.lboro.ac.uk/gawc/rb/rb227.html) (accessed on 19 May 2008).

THIERSTEIN A. and FÖRSTER A. (Eds) (2008) The Image and the Region: Making Mega-City Regions Visible! Lars Müller Publishers, Baden.

THIERSTEIN A., KRUSE C., GLANZMANN L., GABI S. and GRILLON N. (2006) Raumentwicklung im Verborgenen. Die Entwicklung der Metropolregion Nordschweiz. Verlag Neue Zürcher Zeitung, Zürich. 
TUROK I. and BAILEY N. (2004) The theory of polynuclear urban regions and its application to Central Scotland, European Planning Studies 12, 371-389.

UNFPA (UNITED NATIONS POPULATION FUND) (2007) State of World Population 2007: Unleashing the Potential of Urban Growth. UNFPA, New York.

WHEELER S. (2008) Regions, megaregions, and sustainability, Regional Studies, doi: 10.1080/00343400701861344.

YARWOOD J. (Ed) (2006) The Dublin-Belfast Development Corridor: Ireland's Mega-City Region? Ashgate, Aldershot. 


\section{NOTES}

${ }^{1}$ The international consortium was co-ordinated by Peter Hall and Kathy Pain at the Young Foundation (formerly Institute of Community Studies) in London from 2003 to 2006 and included a further eight European research institutions: Universiteit van Amsterdam; Université Libre de Bruxelles; University College Dublin; Institut für Landes- und Stadtentwicklungsforschung des Landes Nordrhein-Westfalen, Dortmund; Universität Heidelberg; Loughborough University; Université Paris 1; and Eidgenössische Technische Hochschule Zürich.

${ }^{2}$ We have adopted the terminology used in POLYNET in this introductory paper. HALL and PAIN (2006, p. 3) define the 'mega-city region' as 'a series of anything between 10 and 50 cities and towns, physically separate but functionally networked, clustered around one or more larger central cities, and drawing enormous economic strength from a new functional division of labour'. This is similar in concept to SCOTT's (2001a) 'global city-region', an exemplar acknowledged by HALL and PAIN (2006, p. 12; see also HALL, 2001). We use both terms synonymously here but would argue that 'global city-region' captures the focus on economic-functional linkages better than 'mega-city region' with its demographic connotation of rapid urban growth (note the different use of hyphen), especially in a European context (see TAYLOR (1999) for a discussion of the dangers of conflating the concepts of global city and mega-city; a point that equally applies to the city-regional dimension discussed here). Both terms share their focus on large (however defined) polycentric city-regions with the term 'megaregion' used in the US planning context (e.g. DEWAR and EPSTEIN, 2007; GOLDFELD, 2007).

${ }^{3}$ In addition, individual research teams have published regionally focused monographs (THIERSTEIN et al., 2006; YARWOOD, 2006) or specialist papers dealing with specific analytical or methodological aspects of the POLYNET project (e.g. AUJEAN et al., 2007; GREEN, 2007; SCHMITT and KNAPP, 2006). 